\title{
How sulphur dioxide and storage temperature contribute to patulin degradation in homemade apple juice
}

\author{
Martina Bevardi ${ }^{1}$, Marinko Petrović ${ }^{1}$, Ksenija Markov $^{2}$, and Jasna Bošnir ${ }^{1}$ \\ Andrija Štampar Teaching Institute of Public Health', Faculty of Food Technology and Biotechnology', \\ Zagreb, Croatia
}

[Received in January 2018; Similarity Check in January 2018; Accepted in May 2018]

\begin{abstract}
Mycotoxin patulin is one of the quality indicators for apple juice. Like other mycotoxins, it raises consumer health concerns. The issue of low quality is particularly relevant for apples provided by small producers, whose quality control may not be standardised. As sulphur dioxide $\left(\mathrm{SO}_{2}\right)$ is common in fruit preservation against fungi, the aim of this study was to determine how efficient it is in degrading patulin in apple juices stored in real-life conditions. This included refrigerated $\left(4^{\circ} \mathrm{C}\right)$ and non-refrigerated warehouses/environments $\left(30^{\circ} \mathrm{C}\right)$ over $8,10,12$, and 20 weeks of storage. Apple juice was diluted to $0.010 \mu \mathrm{g} \mathrm{g}^{-1}, 0.050 \mu \mathrm{g} \mathrm{g}^{-1}$, and $0.100 \mu \mathrm{g} \mathrm{g}^{-1}$ of patulin. $\mathrm{SO}_{2}$ was added to each sample in the amounts of $250 \mu \mathrm{g} \mathrm{mL}^{-1}$ and $50 \mu \mathrm{g} \mathrm{mL} \mathrm{L}^{-1}$. Untreated juice samples for each patulin concentration served as controls under the same experimental conditions. Patulin content was determined with high performance liquid chromatography. The best degradation was observed with $250 \mu \mathrm{g} \mathrm{mL}^{-1}$ of $\mathrm{SO}_{2}$ at $30^{\circ} \mathrm{C}$ regardless of the patulin baseline concentration. Although treatment with $\mathrm{SO}_{2}$ and refrigeration did not fully remove patulin, it was highly efficient over twelve weeks of storage. Our results suggest that patulin levels can be reduced between 33 and $100 \%$ at $30{ }^{\circ} \mathrm{C}$ and up to $100 \%$ at $4{ }^{\circ} \mathrm{C}$.
\end{abstract}

KEY WORDS: contamination; fruit juice; high performance liquid chromatography; mycotoxin; Penicillium expansum

Patulin is a mycotoxin produced by the Penicillium, Aspergillus, and Byssochlamys fungal species. It is found in various mouldy fruits, grains, and foods, but is most often associated with contamination of apples and their products (1). The growing apple and apple juice production calls for better quality control, especially with regard to toxic substances like patulin. Particularly vulnerable in terms of health risk are children due to their lower body weight and higher consumption. A recent study has suggested that contamination with patulin could be prevented by removing apple parts showing visible fungal decay (2) or reduced by processing, but its incidence in food products throughout the world witnesses to its stability and resistance to the production methods currently in use $(3,4)$.

Patulin was first studied as a potential new antibiotic, but research soon demonstrated its adverse effects (5). In rodents, the oral $\mathrm{LD}_{50}$ of patulin is $29-50 \mu \mathrm{g} \mathrm{g}^{-1}$ of body weight. It is reported to be acutely toxic to mice, teratogenic to chicken embryos, and immunosuppressive in mice and rabbits. Furthermore, it is able to inactivate enzymes, mainly as a consequence of its strong affinity for sulphhydryl groups (6). Due to the evidence of its toxicity, the Codex Alimentarius and the US Food and Drug Administration (FDA) have recommended a maximum level of $0.05 \mu \mathrm{g} \mathrm{mL}^{-1}$ for fruit juices and their products $(7,8)$. The European

Correspondence to: Martina Bevardi, Andrija Štampar Teaching Institute of Public Health, Mirogojska cesta 16, 10000 Zagreb

E-mail:martina.bevardi@stampar.hr
Commission (EC) regulation 1881/2006 (9), in turn, set the recommended limit to $0.025 \mu \mathrm{g} \mathrm{mL}^{-1}$ for solid apple products and $0.010 \mu \mathrm{g} \mathrm{mL}^{-1}$ for juices and foods for infants.

Recent reports speak of a number of natural and/or synthetic compounds that inhibit mycotoxin growth and production in a variety of commodities (10-13). Some of them focused specifically on the reduction of apple rot and patulin production (14-17).

Sulphur dioxide $\left(\mathrm{SO}_{2}\right)$ is a common preservative used in food industry because of its antifungal activity. In fact, it strongly inhibits mycelium growth and patulin production $(3,10,12,18-20)$. This suggests that it could be used to make up for poor quality control and storage conditions.

The aim of this study was to evaluate its efficiency as a preservative in apple juices stored at different temperatures and storage times that correspond to real-life conditions. The HPLC method for quantitative determination of patulin in samples was developed and validate it in terms of linearity, selectivity, trueness, precision, limit of detection, limit of quantification, and ruggedness.

\section{MATERIALS AND METHODS}

\section{Apples}

We used damaged and partly rotten apples of an old Croatian variety collected at a local family orchard. 


\section{Juice preparation}

The juice was obtained by crushing $5 \mathrm{~kg}$ of unwashed apples in a hydraulic kitchen press.

\section{Chemicals}

High-performance liquid chromatography (HPLC) grade acetonitrile (CAS 75-05-8) was obtained from J. T. Baker (Arnhem, the Netherlands). Perchloric acid (CAS 7601-90-3), diethyl ether (60-29-7), acetic acid (CAS 6419-7), ethyl acetate (CAS 141-78-6), and sodium bicarbonate (CAS 144-55-8) were obtained from Kemika (Zagreb, Croatia). The patulin (CAS 149-29-1) standard was obtained from Sigma (Steinheim, Germany). The water used for all solutions and HPLC analysis was purified with the Milli-Q system (Merck Millipore, Burlington, MA, USA). Pectinase (EC 3.1.1.11) was obtained from Polyintell (Val-de-Reuil, France).

\section{Sample preparation and HPLC analysis}

All experiments were performed with homemade apple fruit juice without additives. Patulin concentrations were determined with HPLC. The initial concentration measured in juice was $0.251 \mu \mathrm{g} \mathrm{g}^{-1}$, which was then diluted with $2 \%$ acetic acid to get the baseline patulin concentrations of $0.100 \mu \mathrm{g} \mathrm{g}^{-1}, 0.050 \mu \mathrm{g} \mathrm{g}^{-1}$, and $0.010 \mu \mathrm{g} \mathrm{g}^{-1}$. Each solution was made in triplicate. To prevent exposure to light we used tinted flasks.

The first flask was spiked with $250 \mu \mathrm{g} \mathrm{mL}^{-1}$ of $\mathrm{SO}_{2}$, the second with $50 \mu \mathrm{g} \mathrm{mL}^{-1}$, and the third was not spiked (control). Half of the prepared solutions were kept in a refrigerator $\left(4^{\circ} \mathrm{C}\right)$ and the other half in the thermostat set at $30^{\circ} \mathrm{C}$ for five months. Patulin was analysed after eight, ten, twelve, and twenty weeks.

The samples for patulin HPLC analysis were prepared in SupelMIP ${ }^{\circledR}$ solid phase extraction (SPE) tubes (Supelco, Bellefonte, USA) using molecularly imprinted polymers to create a three-dimensional network that recognises the shape and functional group positions of a template molecule.

The apple juice was first subjected to the activity of the enzyme pectinase (Polyintell) to become clear.

For analysis we took portions of $2.5 \mathrm{~mL}$, weighed them, diluted with $2.5 \mathrm{~mL}$ of $2 \%$ acetic acid, and mixed. The obtained solution was loaded on the SPE column by gravity. To condition the column, $2 \mathrm{~mL}$ of acetonitrile were passed through the column, and then $1 \mathrm{~mL}$ of water and $1 \mathrm{~mL}$ of the diluted sample were added. The column was washed with $1 \mathrm{~mL}$ of $1 \%$ sodium bicarbonate and $2 \mathrm{~mL}$ of water, and after drying the column under vacuum, $500 \mu \mathrm{L}$ of diethyl ether was passed through it. Patulin was eluted with $2 \mathrm{~mL}$ of ethyl acetate, and one drop of pure acetic acid was added to the eluent to prevent patulin degradation. The eluent was evaporated to dryness under nitrogen. Immediately after drying, we added $500 \mu \mathrm{L}$ of $0.1 \%$ acetic acid.
For analysis we used the 1200 HPLC system (Agilent, Santa Clara, CA, USA) with the following setup: Synergi Hydro-RP column, 4.6 x 150 mm, 4 m (Phenomenex, Torrance, CA, USA); $5 \%$ acetonitrile and $0.19 \%$ perchloric acid for mobile phase; $0.2 \mathrm{~mL} \mathrm{~min}^{-1}$ flow rate. The detection wavelength was set at $276 \mathrm{~nm}$ and the sample injection volume was $50 \mu \mathrm{L}$. Total run time was $20 \mathrm{~min}$.

\section{Validation of the applied method}

The method was validated for its linearity, selectivity, trueness, precision, limit of detection (LOD), limit of quantification (LOQ), and ruggedness. Linearity was tested in the range of $0.01-0.132 \mu \mathrm{g} \mathrm{g}^{-1}$. The calibration curve was plotted at eight levels. The trueness of the method was investigated based on the mean recoveries of three spiked sample replicates at each level. Precision, estimated under repeatability conditions and within the reproducibility range, was expressed as a relative standard deviation of the spiked replicates at each of the studied levels. Selectivity was determined based on the profile of chromatograms obtained for standard patulin solutions, patulin-free, and patulin-spiked juice. The ruggedness of the method was tested by registering small changes within the extraction times $(0.5 \mathrm{~min}$ and $5 \mathrm{~min}$ ) and evaporation times ( $5 \mathrm{~min}$ and $15 \mathrm{~min}$ ). The method was verified by inter-laboratory comparison with an accredited laboratory (FAPAS, Sand Hutton, UK; z-score $\leq 2$ ).

\section{RESULTS AND DISCUSSION}

The LOD and LOQ, established using standard solutions, were $0.0005 \mu \mathrm{g} \mathrm{g}^{-1}$ and $0.001 \mu \mathrm{g} \mathrm{g}^{-1}$, respectively. The results given in Table 1 prove that the method is satisfactory for the determination of patulin in apple juices. The validation procedure resulted in acceptable mean recoveries of $94-100 \%$, as well as in acceptable mean intermediate precision of $5.12 \%$. The same goes for the variation coefficients $(\mathrm{RSD}<10 \%)$. Our study has shown that the time needed to reduce patulin depends on storage temperature, initial patulin concentration, and the concentration of $\mathrm{SO}_{2}$.

Table 1 The results of the patulin analysis method validation

\begin{tabular}{|c|c|c|c|}
\hline Parameter & & & Obtained value \\
\hline Linearity & & & $\mathrm{k}=0.9999$ \\
\hline Trueness & & & $94-100 \%$ \\
\hline Precision & & RSD & $5.12 \%$ \\
\hline LOD & & & $0.0005 \mu \mathrm{g} \mathrm{g}^{-1}$ \\
\hline LOQ & & & $0.0010 \mu \mathrm{g} \mathrm{g}^{-1}$ \\
\hline Selectivity & & & Satisfactory \\
\hline \multirow{2}{*}{$\begin{array}{c}\text { Ruggedness } \\
\text { (extraction time) }\end{array}$} & $0.5 \mathrm{~min}$ & RSD & $4.90 \%$ \\
\hline & $5.0 \mathrm{~min}$ & RSD & $4.99 \%$ \\
\hline \multirow{2}{*}{$\begin{array}{c}\text { (evaporation } \\
\text { time) }\end{array}$} & $5.0 \mathrm{~min}$ & RSD & $4.98 \%$ \\
\hline & $15.0 \mathrm{~min}$ & RSD & $32.5 \%$ \\
\hline
\end{tabular}


Figure 1 shows the effect on patulin reduction in apple juice over 20 weeks of incubation at $30{ }^{\circ} \mathrm{C}$. The strongest effect (reduction to below LOQ of $0.001 \mu \mathrm{g} \mathrm{g}^{-1}$ ) was observed for the treatment with the highest $\mathrm{SO}_{2}$ concentration regardless of the baseline patulin concentration, which supports the findings of Tabatabaie et al. (3) that higher temperatures favour patulin degradation. A similar reduction of the Byssochlamys nive biomass was reported for the combination of $\mathrm{SO}_{2}$ and temperature of 24,30 , and $37^{\circ} \mathrm{C}$ by Ough and Were (21). Temperature treatments, however, can diminish clarity and organoleptic properties of such juices (3). Koca et al. (22) also reported a 78-100\% reduction of patulin in samples treated with ascorbic acid alone (without $\mathrm{SO}_{2}$ ) and stored at $30^{\circ} \mathrm{C}$, but note that even our control samples showed complete degradation with lowest baseline patulin concentrations.

However, untreated patulin at the highest baseline concentrations of $0.100 \mu \mathrm{g} \mathrm{g}^{-1}$ did not drop below the limit for safe consumption recommended by the EC (9) for fruit juices $\left(0.050 \mu \mathrm{g} \mathrm{g}^{-1}\right)$ in the first eight weeks of storage, which means that contamination with higher patulin levels requires treatment with $\mathrm{SO}_{2}$ at higher temperatures (e.g. $30{ }^{\circ} \mathrm{C}$ in our study) with incubation of over eight weeks. With the exception of the above mentioned case, no significant differences were observed between control (baseline patulin concentrations of $0.050 \mu \mathrm{g} \mathrm{g}^{-1}$ and $0.100 \mu \mathrm{g} \mathrm{g}^{-1}$ ) and samples treated with $50 \mu \mathrm{g} \mathrm{mL}^{-1} \mathrm{SO}_{2}$. Here patulin degradation for both experimental concentrations during 20 weeks was almost similar.

Figure 2 shows patulin reduction in samples refrigerated at $4{ }^{\circ} \mathrm{C}$. Compared to storage at $30{ }^{\circ} \mathrm{C}$ (Figure 1), it is noticeably less effective, except for the baseline patulin concentration of $0.010 \mu \mathrm{g} \mathrm{g}^{-1}$ treated with the highest $\mathrm{SO}_{2}$ concentration of $250 \mu \mathrm{g} \mathrm{mL}^{-1}$, where patulin levels dropped below the LOQ. However, lower $\mathrm{SO}_{2}$ concentrations entailed lower patulin degradation.

Patulin has been shown to be unstable in the presence of sulphur-containing compounds (23). A study of Burroughs et al. (24) reported a $90 \%$ of patulin reduction after two days of treatment with a $200 \mathrm{ppm} \mathrm{SO}_{2}$ solution.

$$
\text { - } \mid \text { weeks incubation }=12 \text { weeks incubation }=16 \text { weeks incubation }=20 \text { weeks incubation }
$$

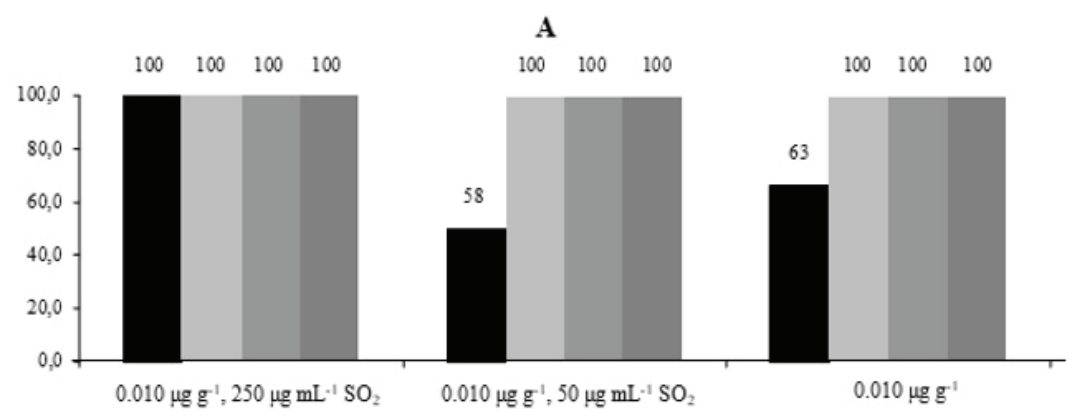

B

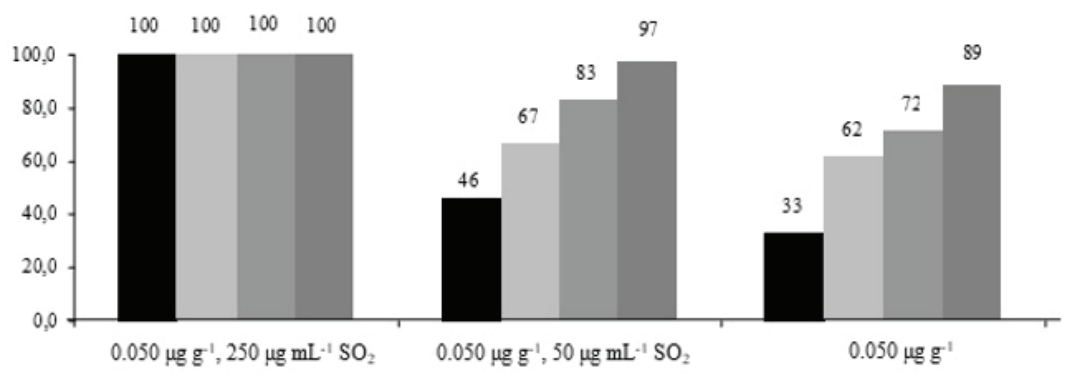

C

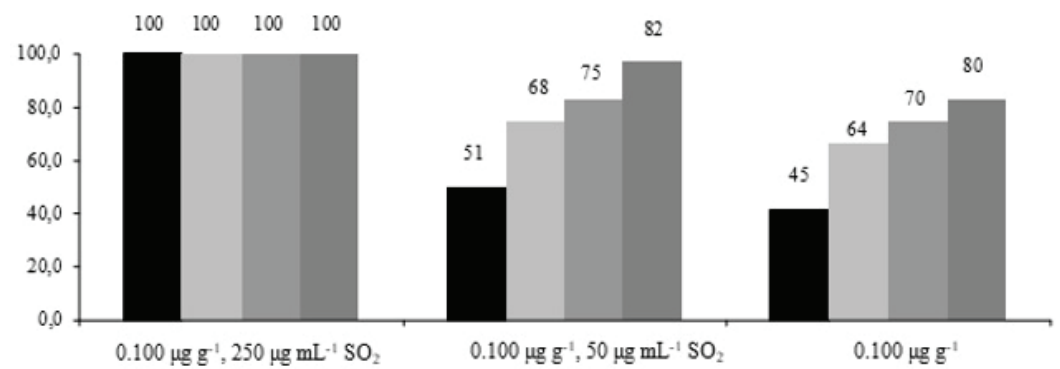

Figure 1 Percentage of patulin reduction during storage at $30^{\circ} \mathrm{C}$. Baseline patulin concentrations: $A-0.010 \mu g g^{-1} ; B-0.050 \mu g . g^{-1}$; $C-0.100 \mu g g^{-1}$ 


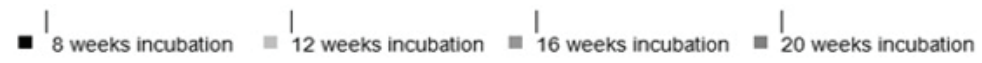

A

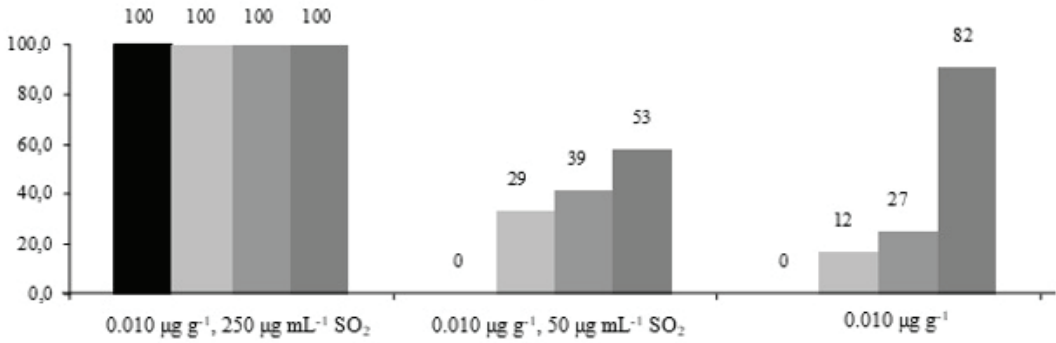

B

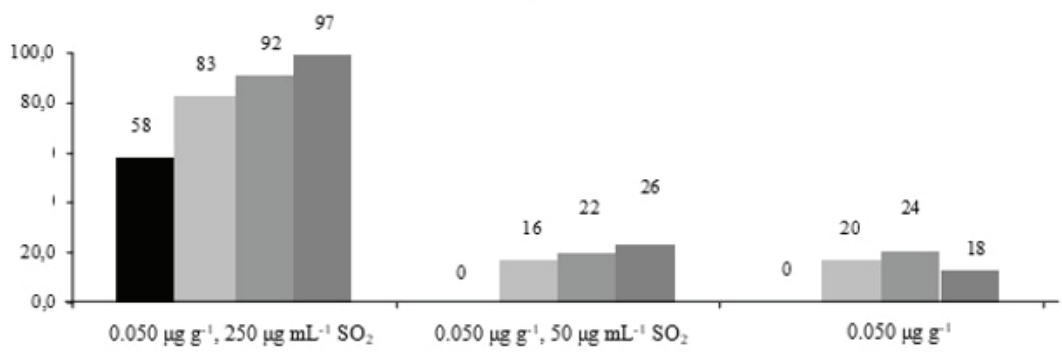

C

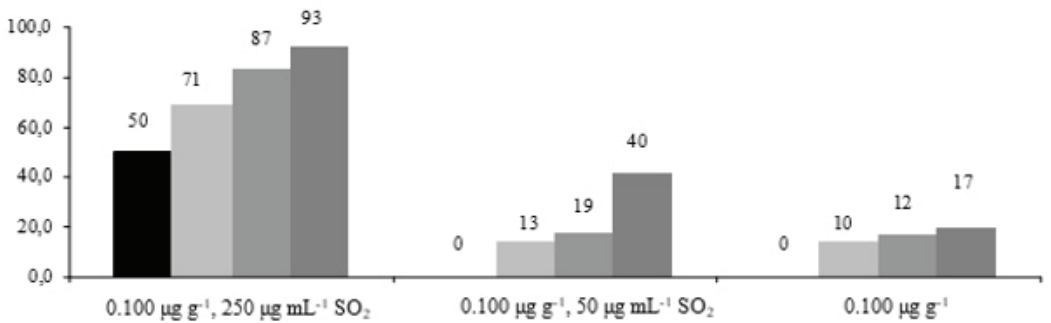

Figure 2 Percentage of patulin reduction during storage at $4{ }^{\circ} \mathrm{C}$. Baseline patulin concentrations: $A-0.010 \mu g g^{-1} ; B-0.050 \mu g . g^{-1}$; $C-0.100 \mu g^{-1}$

Cavallito et al. (25) later reported that only $100 \mathrm{ppm}$ of sulphur dioxide reduced patulin content by $50 \%$ in $15 \mathrm{~min}$. The differences between these reports and our findings could be attributed to differences in the composition of the sample solutions, as interfering components may have been present. Patulin is also believed to react with a number of other sulphur-containing compounds such as cysteine, $\mathrm{N}$-acetylcysteine, and glutathione (12) because it has a strong affinity for binding covalently to sulfhydryl groups as well as to amino, thiol, and NH2 groups (26). While the resulting adducts are still toxic, their toxicity is 100 times lower than that of patulin $(27,28)$.

In summary, among the 36 apple juice samples with six patulin and $\mathrm{SO}_{2}$ combinations, $70 \%$ showed reduction to levels below the EC safety limit (9). This suggests that adjusting $\mathrm{SO}_{2}$ and storage temperatures is a promising approach for fruit juice industries to preventing contamination with patulin.

Future studies should include variations in temperature and $\mathrm{SO}_{2}$ concentrations to determine the lowest conditions for patulin reduction and their influence on organoleptic properties of the juices.

\section{REFERENCES}

1. Food and Agriculture Organization (FAO). Code of practice for the prevention and reduction of patulin contamination in apple juice and apple juice ingredients in other beverages CAC/RCP 50-2003 [displayed 14 August 2018]. Available at http://www.fao.org/input/download/standards/405/ CXP_050e.pdf.

2. Bandoh S, Takeuchi M, Ohsawa K, Higashihara K, Kawamoto Y, Goto T. Patulin distribution in decayed apple and its reduction. Int Biodeter Biodegr 2009;63:379-82. doi: 10.1016/j.ibiod.2008.10.010

3. Tabatabaie F, Ali Mortazavi S, Tabatabaee F, Ebadi AG. Reduction of patulin in apple juice after treatment with $\mathrm{SO}_{2}$ and heat. Indian J Sci Technol 2010;5:596-9.

4. de Souza Sant'Ana A, Rosenthal A, Rodrigez de Massaguer P. The fate of patulin in apple juice processing: A review. 
Food Res Int 2008;41:441-53. doi: 10.1016/j foodres.2008.03.001.

5. Baert K, De Meulenaer B, Kasase C, Huyghebaert A, Ooghe W, Devlieghere F. Free and bound patulin in cloudy apple juice. Analytical, nutritional and clinical methods. Food Chem 2007;100:1278-82. doi: 10.1016/j.foodchem. 2005.10.012.

6. Puel O, Galtier P, Oswald IP. Biosynthesis and toxicological effects of patulin. Toxins 2010;2:613-31. doi: 10.3390/ toxins2040613.

7. Codex Committee on Food Additives and Contaminants (CODEX). Maximum level for patulin in apple juice and apple juice ingredients and other beverages [displayed 22 August 2017]. Available at https://ec.europa.eu/food/sites/ food/files/safety/docs/codex_cac_26_comments-1_en.pdf.

8. United States Food and Drug A- Aministration (ŪS FDA). Patulin in apple juice, apple juice concentrates and apple juice products [displayed 22 August 2017]. Available at $h t t p: / /$ www.micotoxinas.com.br/boletim37.pdf.

9. Commission Regulation (EC) no. 1881/2006 of 19 December 2006 setting maximum levels for certain contaminants in foodstuffs [displayed 22 August 2017]. Available at https:// eur-lex.europa.eu/legal-content/EN/TXT/ $P D F / ?$ uri $=$ CELEX:32006R1881\& from $=E N$.

10. Podgórska E. Effect of preservatives on patulin production by Penicillium expansum. Acta Microbiol Pol 1992;41:97107. PMID: 1283493.

11. Bevardi M, Frece J, Mesarek D, Bošnir J, Mrvčić J, Delaš F, Markov K. Antifungal and antipatulin activity of Gluconobacter oxydans isolated from apple surface. Arh Hig Rada Toksikol 2013;64:281-6. doi: 10.2478/10004-1254-642013-2308.

12. Hussain A, Shafqatullah, Ali J, Zia-ur-Rehman. Inhibition of aflatoxin producing fungus growth using chemical, herbal compound/spices and plants. Pure Appl Biol 2012;1:8-13.

13. Ismaiel AA, Papenbrock J. Mycotoxins: Producing fungi and mechanisms of phytotoxicity. Agriculture 2015;5:492-537. doi: 10.3390/agriculture5030492.

14. Markov K, Mihaljević B, Domijan A, Pleadin J, Delaš F, Frece J. Inactivation of aflatoxigenic fungi and the reduction of aflatoxin $\mathrm{B}_{1}$ in vitro and in situ using gamma irridation. Food Control 2015;54:79-85. doi: 10.1016/j. foodcont.2015.01.036.

15. Welke JE, Hoeltz M, Dottori HA, Noll IB. Effect of processing stages of apple juice concentrate on patulin levels.
Food Control 2009;20:48-52. doi: 10.1016/j. foodcont.2008.02.001.

16. Moake mm, Padilla-Zakour OI, Worobo RW. Comprehensive review of patulin control methods in foods. Compr Rev Food Sci F 2005;4:8-21. doi: 10.1111/j.1541-4337.2005.tb00068.x.

17. Jackson LS, Beacham-Bowden T, Keller SE, Adhikari C, Taylor KT, Chirtel SJ, Merker RI. Apple quality, storage and washing treatments affect patulin levels in apple cider. J Food Prot 2013;66:618-24. PMID: 12696685.

18. Reddy KRN, Abbas HK, Abel CA, Shier WT, Salleh B. Mycotoxin contamination of beverages: Occurrence of patulin in apple juice and ochratoxin A in coffee, beer, wine and their control methods. Toxins 2010;2:229-61. doi: 10.3390/toxins2020229.

19. Barkai-Golan R. Penicillium mycotoxins. In: Barkai-Golan R, Paster N, editors. Mycotoxins in Fruit and Vegetables. $1^{\text {st }}$ ed. London: Elsevier Inc.; 2008. p. 153-83.

20. Cantin CM, Palou L, Bremer V, Michailides TJ, Crisosto CH. Evaluation of the use of sulfur dioxide to reduce postharvest losses on dark and green figs. Postharvest Biol Tec 2011;59:150-8. doi: 10.1016/j.postharvbio.2010.09.016.

21. Ough CS, Were L. Sulfur dioxide and sulfites. In: Davidson MP, Sofos JN, Branen AL, editors. Antimicrobials in Food. $3^{\text {th }}$ ed. Boca Raton: Taylor \& Francis Group; 2005. p. 143-67.

22. Koca N, Ekşi A. Reduction of patulin in apple juice concentrates during storage. J Food Saf 2004;25:1-8. doi: 10.1111/j.0149-6085.2005.25538.x.

23. Pohland A, Allen R. Stability studies with patulin. J AOAC 1970;53:688-91.

24. Burroughs L. Stability of patulin to sulfur dioxide and to yeast fermentation. J Assoc Off Anal Chem 1977;60:100-3.

25. Cavallito C, Bailey J. Preliminary note on the inactivation of antibiotics. Science 1944;100:390.

26. Wu TS, Liao YC, Yu FY, Chang CH, Liu BH. Mechanism of patulin-induced apoptosis in human leukemia cells (HL-60). Toxicol Lett 2008;183:105-11.

27. Lindroth $S$, von Wright A. Detoxification of patulin by adduct formation with cysteine. J Environ Pathol Toxicol Oncol 1990;10:254-9.

28. Fliege R, Metzler M. Electrophilic properties of patulin. Adduct structures and reaction pathways with 4-bromothiophenol and other model nucleophiles. Chem Res Toxicol 2000;13:363-72. 


\section{Utjecaj sumpornog dioksida i temperature skladištenja na razgradnju patulina u domaćem jabučnom soku}

Mikotoksin patulin jedan je od pokazatelja kakvoće jabučnog soka. Poput drugih mikotoksina, prisutnost patulina predstavlja zdravstveni problem. Pitanje loše kakvoće jabuka odnosi se na mala obiteljska gospodarstva, gdje se kakvoća korištenih jabuka ne može standardizirati. Prisutnost plijesni i mikotoksina zdravstveni je problem, a SO pospješuje razgradnju patulina. Svrha ove studije bila je odrediti razgradnja patulina u jabučnom soku tretiranim $\mathrm{sa}_{2} \mathrm{SO}_{2}$ pri različitim temperaturama skladištenja. Utjecaj $\mathrm{SO}$ na razgradnju patulina ispitivana je u uzorcima pohranjenima u svakodnevnim uvjetima. To uključuje hladnjak $\left(4^{\circ} \mathrm{C}\right)$ i nehlađena skladišta/okoliš $\left(30^{\circ} \mathrm{C}\right)$ tijekom $8,10,12$ i 20 tjedana. Jabučni sok razrijeđen je na koncentracije $0,010 \mu \mathrm{g} \mathrm{g}^{-1}, 0,050 \mu \mathrm{g} \mathrm{g}^{-1}$ i $0,100 \mu \mathrm{g} \mathrm{g}^{-1}$ patulina. U svaki uzorak dodan je $\mathrm{SO}_{2} \mathrm{u}$ količini od $250 \mu \mathrm{g} \mathrm{mL}^{-1}$ i $50 \mu \mathrm{g} \mathrm{mL} \mathrm{m}^{-1}$. Uzorci soka u koji nije dodan $\mathrm{SO}_{2}$ za svaku koncentracijsku razinu patulina poslužili su kao kontrola i bili su pod istim eksperimentalnim uvjetima. Patulin u uzorcima određivan je pomoću tekućinskog kromatografa visoke djelotvornosti (HPLC). Najveća razgradnja patulina zabilježena je u termostatskim uvjetima s koncentracijom $\mathrm{SO}_{\text {od }} 250 \mu \mathrm{g} \mathrm{mL}^{-1}$, bez obzira na koncentraciju patulina kontrolnog uzorka. Iako hlađeni uvjeti i dodatak $\mathrm{SO}_{2}$ nisu potpuno uklonili patulin iz uzoraka, nakon dvanaest tjedana skladištenja uočena je visoka učinkovitost razgradnje. Rezultati pokazuju da se razine patulina mogu smanjiti 33-100\% pri temperaturi od $30{ }^{\circ} \mathrm{C}$ i $0-100 \%$ pri $4{ }^{\circ} \mathrm{C}$.

KLJUČNE RIJEČI: kontaminacija; voćni sok; tekućinska kromatografija visoke djelotvornosti; mikotoksin; Penicillium expansum 